\title{
THE CONCEPT OF VALUES \\ IN FLORIAN ZNANIECKI'S EARLY WORK
}

\author{
Michał R. Kaczmarczyk \\ University of Gdańsk
}

The concept of value has lost much of the theoretical and rhetorical power it possessed in the early twentieth century. One of Jürgen Habermas's and Niklas Luhmann's central interests was to demonstrate that other mechanisms could fulfil the integrative function in society. Values became more and more concomitant with moral conflicts rather than harmony and integration. In addition, relativistic perspectives deprived values of stable normative contents that could serve as orientation points in a world of accelerating social change. At the same time, the idea of "common values" still seems to resonate with the broader public.

The supposition that values were in crisis and the critique of values as empty phrases both involved a specific understanding of values and their definition as a stable, universalistic component of the social order. However, in the early twentieth century, when theoretical debates on values flourished, the concept also embraced opposite ideas of changeability, flexibility, and social dynamics. In the present paper I am going to argue that Florian Znaniecki's early concept of value was intended to provide the idea of creative dynamics for social theory. His attempt found little resonance in the United States and has been overshadowed by the functionalist theory of Talcott Parsons. On the other hand, the tradition of symbolic interactionism took inspiration mostly from the work of George Herbert Mead, who did not give the concept of values that importance in his theoretical work. The aim of the present article is to reconstruct the main ideas of 
Znaniecki's early theory of values in order to demonstrate its advantages in constructing social theory.

\section{/// The Discovery of Values}

The concept of value, which emerged at the turn of the nineteenth to twentieth centuries, spread and continued to be widely used after the Second World War. Although the term "value" had already been used by Kant and by his followers throughout the nineteenth century, its tremendous career in the social sciences was sparked by Friedrich Nietzsche's idea of the historical and psychological genesis of morality (Joas 1997: 37-57). At the same time, the sociologists Max Weber and Émile Durkheim introduced the idea of common values in individualistic models of action, defining "value" as one of several important objects of sociological studies (Weber 1922: 12-13; Durkheim 1951 [1897]: Ch. 5). Values, as a distinct phenomenon of individual experience and a source of universalistic social norms, drew the attention of pragmatists and phenomenologists early on.

The theoretical fascination with values culminated in Talcott Parsons's theory (1937), which became mainstream and claimed value consensus to be the basis of social integration and to be constitutive of the intelligibility of other social functions. The elevation of values to the level of social control from the level of individual experience required one crucial step which was actually made before Parsons by his colleague Clyde Kluckhohn (1951: 396). Values had been defined not as mere preferences or ideas of what is good but as second-order preferences controlling and navigating the spontaneous or instinctive first-order preferences. "Work," "learning," or "helping people" are values as far as they are not prima facie preferred but still prevail by allowing an individual to evaluate and suppress her own wishes.

It is easy to see that along with Kluckhohn and Parsons's definition of values the old Platonic idea of internal conflicts of the soul returns to the social sciences. Another aspect of this return was Stanisław Ossowski’s (2000 [1967]: 84-89) differentiation - which inspired at least two generations of Polish sociologists - between instrumental and ultimate values. Despite the sophistication of the Parsonian paradigm, which distinguished the social sciences from classical economic thinking, the idea of second-order values has problems of its own. One of these appears clearly in the Weberian concept of value-orientation, which can be easily reduced to goal-orientation and deprived of its logical force (Boudon 2001: 93-117). The question of 
how values emerge and what makes them socially irreducible remains valid. Values defined as a separate sphere or as analytical categories cannot be located in social reality unless there is resort to a metaphysical tradition, as Durkheim famously attempted. To avoid the dissolution of values in abstract descriptions or their displacement to a non-empirical world, values would have to be located in empirically accessible reality both as a personal experience and as a social function. This is exactly where, in my opinion, Znaniecki's idea of values demonstrates its usefulness (1987 [1909]: 21), even though it may seem to be more superficial, as it does not oppose values to mere preferences (Thome 2008: 279-281). The most obvious and literal interpretation would identify values in Znaniecki's philosophy with things as they are seen from the actor's perspective. Such a misreading would overlook one important point: for Znaniecki, values are not epiphenomena or images of things but are ontologically and epistemically primary to things, as they are to any other cognitive object. For instance, values are more fundamental than moral norms since the latter are always broken up into causal and teleological chains. In order to be moral, one has to intend the good and, at the same time, to deduce it from first principles. The two operations are not commensurable and presuppose values. In his early text on philosophical ethics and moral values (1987 [1909]), Znaniecki came to the radical conclusion that moral philosophy is not possible in light of the historical relativity of values.

\section{/// Values and Reality}

Znaniecki's idea of values differs from the Parsonian definition because it responds to a different problem. Znaniecki does not ask about the suppression of an individual's own preferences but about the possibility of stable ground in the ocean of constantly changing values. Because he states the problem differently, Znaniecki, contrary to Parsons, does not presuppose the existence of values or a social consensus about them, but focuses on their genesis - a matter virtually omitted in the Parsonian version of culturalism. Parsons did not have a problem with the presupposed objectivity of values because he did not take their social and dynamic aspect seriously enough. Znaniecki wrote that "the social and objective character of values contradict each other" (1987 [1909]: 24) and further that "there is no a priori principle to assign any primacy to the social rather than individual action of values" (1987 [1909]: 24). 
In a later article on thought and reality (1987 [1911]) Znaniecki attempted for the first time to define the sphere of values and find their specific location. The result is a theory of action and temporality resembling the later ideas of Mead, as elaborated in his Philosophy of the Present (1932: 6-28). Znaniecki argues that the differentiation of thought and reality, which bothered so many philosophers, may be derived from the temporality of action, which objectifies its own stable functions as objects while remaining a dynamic process of thought. The action is not limited by goals or means but by the present, which constantly produces both pasts and futures. Values are most real in the present as the action provokes new contents and synthesises the old ones. However, values are atemporal in that they can be revoked at any moment. The time of values may be reversed, because the logic of values is not causal. Natural scientists have good reasons to differentiate the past and the future but the same difference is relative from the practical perspective: "facts belong to the past or to the future only with reference to the actuality. Namely, all that passed can return and all that will come might have already happened" (1987 [1912]: 95). As Znaniecki argues, the arrows of time fulfil a much more flexible function in the sphere of values by describing the directions of values' becoming: a value can either approach the actuality or increase its distance from it.

The only objective measure of individual values is their position in value systems, which extend beyond individual experiences and opinions. In other words, values constitute intersubjective systems that provide individuals with stable realities. However, for Znaniecki, the social understood in terms of group thinking is an illusion - one that is distinct in the Durkheimian tradition of sociology. In "The Elements of Practical Reality," written in 1912, one year before his first meeting with William I. Thomas, Znaniecki stressed the metaphorical meaning of sociological vocabulary: social orders are no more than metaphors of value systems, and collective representations mean no more than collective points of view in individual minds. Znaniecki describes as "social" those values whose relationships remain the same from the standpoint of all or the majority of individuals. These entities do not live in any privileged type of reality, as, for example, "collective representations" do. On the contrary, their practical genesis makes them vulnerable to reflexive twists and situational vicissitudes. While each action seeks to solve a specific situation with which it is confronted, values gain all their meaning from being elements of action. Two ideas of special importance for Znaniecki's further career ensued from this practical foundation of reality: first, acting individuals are directly oriented 
towards the Good, the immanent presupposition of the intelligibility of action, while values mean the reflexive, theoretically objectified ideas of the Good; second, cross-sectional social studies are doomed to failure as they are not able to reflect the processual reality of action and the dynamic character of values. This early methodological insight of Znaniecki's prepared the way for his later contribution to empirical studies on general value transformation.

\section{/// Values and Action in Znaniecki's and Thomas's Works}

The article "The Significance of World and Human Development," which appeared in 1913 and which Znaniecki probably wrote after his first meeting with Thomas, marked the beginning of a new stage in Znaniecki's intellectual trajectory. Along with a growing interest in the evolution of value systems, the text reveals new ideas in Znaniecki's arguments. He focused not only on the macro-level of cultural processes but also on the micro-level of the situational determination of action. Like the pragmatists, Znaniecki mentions the role of hindrances in modifying a course of action but is far from assigning to hindrances an exclusive or even a crucial role in shaping value-systems - a motif we encounter throughout Thomas's early work. For Znaniecki, hindrances awaken the "consciousness of an external influence before its actual occurrence" but do not exhaust the mechanism of human development. For Thomas, human beings can be reduced to adaptive functions, while Znaniecki conceptualises humans as subjects who create and shape the external world, thus making it completely dependent on them. Human actors are not just inventive in specific situations; they are creative by building a world which is "a world for them," a system of values governed by its own logic - sometimes irrational or paradoxical but still intelligible as an object for the human subjects.

The very fact that Znaniecki introduced into his philosophy elements that are crucial to Thomas's way of thinking may indicate that the mutual theoretical adjustment of the two authors started as soon as 1913. Andrew Abbott and Thomas Egloff (2008), who tried to interpret a change in Thomas's interests that took place approximately at the same time and was reflected in his teaching curricula, deny that Znaniecki had any influence on Thomas and falsely place the first meeting of the two in 1914. Contrary to Abbott and Egloff's suggestions, it may be argued that Thomas and Znaniecki's first encounter initiated their intensive intellectual dialogue (Kaczmarczyk 2018: 291-295; Thomas E.A. 1992; Wiley 2007: 137-139). 
Unlike Thomas's texts, Znaniecki's article on the significance of world and human development is permeated by the idea of a freedom that reaches both to the future and to the past and grows along with the transforming force and complexity of new meanings. At the same time, more stable cultural contents diminish freedom and social development. Znaniecki formulates a dilemma of cognitive and moral stability on the one hand and creative freedom on the other. He writes that "You cannot be free in a secure world, you have to choose between your different wishes: the wish for security and the wish for new experience." Obviously, the same idea may be found throughout Thomas's later work, in particular in The Unadjusted Girl (1923), but it does not seem to be located at the same level of reflection. The constructivist thrust of Znaniecki's philosophy suggests an existential interpretation of his dilemma, while Thomas confines himself to a behavioural analysis, which raises problems of its own, as was classically formulated by Pitirim Sorokin in his critique of "animism" in social theory.

Nevertheless, Thomas is not unaware of the tension between freedom and stability but arrives at this problem in a completely different manner. In his early works he operates on three levels: that of biological instinct (e.g., the famous "gaming instinct" (Thomas 1901)), social control (e.g., the diffusion of imitation (Thomas 1899)) and social knowledge (institutionalised social experimentation and "the habit of change"). All levels imply different mechanisms and finally lead to a contradiction rather than a dilemma, because the biological principle of self-preservation cannot be reconciled with the creativity that spreads both habit and social bonds. The tension between empirical mechanisms analysed by Thomas also appeared to Znaniecki as a theoretical conflict - a situation he solved by his own creativistic theory of action.

We would do injustice to Znaniecki's concept of action by reducing it to the pragmatist idea of relativising goals and means in the classical concept of action. Znaniecki is clearly aware of this accomplishment of the pragmatist theory, but his own method of dealing with the shortcomings of goal-orientation differs in several ways. Apart from providing a constructivist basis of action in the form of values, he identifies the unity of the goal and the actual course of action as the essence of normative ideals (Znaniecki 1987 [1914]). If we consider the Socratic, Buddhist, or Christian visions of the Good we see that they define it more or less metaphorically as an Unknown which has to be achieved in practice without theoretical guidance. Znaniecki aptly expressed this inability of social theory to conceptualise or even perceive the dynamics of values in their creative phase. 
At the same time he outlined his own alternative: a theory that brings together social action, the genesis of norms, and moral personality. In this context values are meant as anything but principles from which a system of norms could be deduced. They are rather the very process that produces new values, norms, and individual personalities.

\section{/// The Role of Values in The Polish Peasant in Europe and America}

The deep philosophical divergences between Thomas and Znaniecki and their parallel interests suggest that their cooperation was a mutually fruitful dialogue. Most interpretations of The Polish Peasant in Europe and America suffer from relative blindness to this context (Abbott \& Egloff 2008; Blumer 1939; Faris 1951; Guth \& Schrecker 2002). They either give the upper hand to Thomas or Znaniecki in creating the work or consider the work to be an almost mechanical synthesis of two commensurable concepts. However, a careful analysis of the authors' previous works makes it evident that they proposed a new theory, which solved their previous theoretical problems, after having confronted a rich body of empirical material. Nonetheless, they had to find a consensus regarding a common theoretical framework before starting the empirical analysis (Kaczmarczyk 2018).

The famous "Methodological Note" is probably the most read chapter of The Polish Peasant. Znaniecki produced three versions of it before reaching an agreement with Thomas. Therefore, it can be interpreted as the best documentation of the authors' dialogue, while its internal tensions reflect the lasting divergences between them, as exemplified by the very starting point of the "Note." On the one hand, the question about new forms of social control that would be adequate for rapid social changes corresponds with Thomas's dilemma. On the other hand, the critique of the biological concept of adaptation and the methodological focus on society in its full development indicate the influence of Znaniecki. Thomas and Znaniecki were in agreement with regard to the necessity of new forms of social control according with the rapidity of change. The problem united two major themes of their previous works: the lack of adequate control and the creative destruction of knowledge and institutions. At the same time they were fully aware that a trial-and-error method could bring social catastrophe to complex modern societies whose control requires systematic and precise knowledge. They were far from the anarchistic ideas of social experimentation that are spreading today under the influence of Bruno Latour. Another important point, which is easy to overlook in Thomas and Znaniecki's 
agenda, is the critique of adaptation-focused social theories. For our authors, adaptation is an active process, never reducible to conditions, and involving a creative redefinition of the situation.

Before outlining the final answer to the problem formulated in the "Methodological Note," one remark on Thomas and Znaniecki's value concept seems necessary. In contrast to those interpreters who view the value-attitude scheme as a mechanical synthesis of the authors' major theoretical concepts, I suggest that the work introduces a new theoretical idea that allows the authors to operationalise Znaniecki's philosophical concept of values. It was in the "Methodological Note" that Znaniecki for the first time indicated the empirical mechanisms of value change and value genesis. Similarly, the idea of triangular causal explanations comprising the influence of attitudes or values on their pre-existing basis appeared as a novel element both in Znaniecki's and Thomas's thought. The idea was progressive in two different ways. First, in terms of methodological economics, the replacement of one explanans with two specific elements meant a vast simplification of the research process. It is much easier to ask how a specific value would change under the influence of a pre-existing set of attitudes than to decide whether this value may cause the invention of another one. Thomas and Znaniecki's explanatory strategy allows, thus, for general laws to be formulated by investigating concrete values in different social contexts. Note that this strategy would not be possible if Thomas and Znaniecki had an abstract, Parsons-like concept of values. According to the definition in the "Methodological Note," a value is "a datum of empirical content accessible to the group members with meaning which can be an object of activity." Values are no less concrete than things, but as opposed to them, they provide actors with meanings which can be ascribed to things in various manners.

While Thomas later distanced himself from the value-attitude scheme, describing it as going too far (Blumer 1939: 83), Znaniecki found it sound, although insufficient in certain respects. We encounter such a view in his book Cultural Reality, which was written simultaneously with The Polish Peasant and published in 1919. It is in this work that Znaniecki clearly juxtaposes the value-attitude scheme to the Durkheimian idea of searching for causes of social facts among other social facts (1919: 295). Further, Znaniecki, apart from repeating the assertions made in The Polish Peasant, recognises the limits of his and Thomas's explanatory scheme by writing that 
A theoretical reconstruction of social becoming based upon the concept of laws evidently cannot pretend to explain the appearance of absolutely new forms of social schemes, since the law as such is always a law of repetition. It can only explain how a scheme, already preexisting in concrete experience, became socialised, realised, and applied in a certain group at a certain epoch, but not how it appeared in the empirical world in general as a result of a new and spontaneous schematic determination of situations which were not schematised before (Znaniecki 1919: 297).

Znaniecki's emphasis on the necessity to explain the very genesis of values and not just their evolution indicates that his divergences from Thomas lingered during their cooperation and afterwards. Moreover, it documents Znaniecki's own research plans, which corresponded well with his early inquiries. The themes that dominate Znaniecki's thought already come to the fore in Part IV of The Polish Peasant, which was written at a time when Thomas was probably less engaged in the work due to the trouble infamously caused to him by the FBI and the University of Chicago. The "Introduction" to Wladek's life not only confirms that the value-attitude scheme goes beyond a mechanical synthesis of biologistic and culturalist concepts but reinforces and elaborates on the non-biologistic understanding of attitudes by dividing their organisation into two distinct types: temperament and character. While the former means no more than association of attitudes on the basis of instinct and habit, the latter involves reflexive reorganisation of attitudes on the basis of social demands. Since both terms refer to empirical regularities of human behaviour, they imply the constitution of habit in individual lives. However, the concept of habit utilised in Thomas's early texts is now strictly limited to the temperamental organisation of attitudes. With regard to character, the authors assert that contrary to biological mechanisms "social situations never spontaneously repeat themselves, every situation is more or less new, for every one includes new human activities differently combined" (Thomas \& Znaniecki 1958: 1852).

Znaniecki's differentiation of personality organisations, in line with his value concept, is anything but an abstract and heuristic tool. On the contrary, it describes concrete subsequent mechanisms that are empirically accessible. Interestingly, the proof of the existence of character as a sophisticated level of attitude organisation is to be found on the biological level: "the attitudes organised for the permanent satisfaction of hunger or sexual 
desire manifest themselves even while no hunger or sexual desire is actually felt and while the actual material conditions do not suggest them in any way" (Thomas \& Znaniecki 1958: 1846).

Similarly, the concept of life-organisation that comprises a set of social values organised at the individual level explains the way in which individuals adapt to changing social demands, thus combining the concept of values with a theory of social control. The latter is not limited to the creation of norms and encroaches on the field of the psychological self-control of experience. However, the control is never static or completed. Each situation opens "the range of possibilities of further development remaining open to the individual after the stabilisation" (Thomas \& Znaniecki 1958: 1853). Under such challenging circumstances the willingness to create new attitudes might be more or less pronounced and three types of personalities describe the poles of possible general orientations: the Philistine, the Bohemian, and the creative.

\section{/// The Advantages of Znaniecki's Concept of Values}

The above-mentioned typology, which applies Znaniecki's early concept of values to the analysis of empirical personality dynamics, suffers from the normative prejudices inscribed in Znaniecki's and Thomas's respect for creative people, but beyond that exhibits several advantages of Znaniecki's theory of values as compared to its sociological alternatives.

First, it is consistently a processual theory for which no static model of personality or society could be true. This leads outright to a methodological postulate to investigate personal development and entire lifespans rather than momentary systems of values or action plans. Life-organisation does not occur at any single moment but is a lifelong challenge. Personal developments and the sequences of values that shape actions are much more important than any particular mental state. Since human beings undergo continual development, the means of life-organisation are much more important than their goals or any particular stage. For this reason Thomas and Znaniecki find cross-cutting research methods essentially deficient, while autobiographies are the only "perfect" types of empirical material. Interestingly enough, Znaniecki would never again use the method of liferecord analysis, while Thomas continued to make use of it, especially in his book The Unadjusted Girl, where he also widely utilised the concept of four wishes. 
Second, the said theory of personality is strongly agency-oriented, thus avoiding the paradoxes and reductionisms relating to structuralist and otherwise determinist approaches. The human action is undetermined at its start; its first phase "is characterised by an essential vagueness" (Thomas \& Znaniecki 1958: 1847) because in spite of the multiple desires that trigger human behaviour, the experienced complexity "is not ordered, values are not outlined" (ibid.). In other words, the source of vagueness is neither lack of will nor lack of social influence, as the theories of social anomie proclaim, but lack of values understood as an individual's own accomplishment.

Third, the introduction of Znaniecki's concept of values allowed the authors of The Polish Peasant to view social organisation and disorganisation as a process in which the equilibrium of both poles shifts in response to changing value systems. The disorganisation of individual lives in times of external challenges may cause social disorganisation, but it may also be the case that conformism is strong enough to suppress the articulation of life disorganisation. Social organisation does not correspond to the state of social or individual consciousness: "It is therefore impossible to conclude from social as to individual organization or disorganization, or vice versa. In other words, social organization is not coextensive with individual morality, nor does social disorganization correspond to individual demoralization" (Thomas \& Znaniecki 1958: 1129). However, by creating new values and demonstrating better-adapted practices individuals are to some extent able to control the process and reach a new equilibrium. Thomas and Znaniecki call the process "social reconstruction," which is possible "only because, and in so far as, during the period of social disorganization a part at least of the members of the group have not become individually disorganized, but, on the contrary, have been working toward a new and more efficient personal life-organization and have expressed a part at least of the constructive tendencies implied in their individual activities in an effort to produce new social institutions." The idea of social reconstruction allows practical desiderata to be formulated but also changes the focus of empirical research. Instead of looking at the general social tendencies reflected in the quantitative data, Thomas and Znaniecki were much more interested in identifying the specific attitudes and values responsible for social disorganisation and reconstruction.

Fourth, Thomas and Znaniecki's theory goes beyond the indication of an integrative function of values and attempts to explain their genesis. In this respect the authors succeed in avoiding Parsons's main failing. As 
we learn from the analysis of the vicissitudes of emigrant life exemplified in the numerous letters described in the first volumes of the book, actors create new values by observing their own new practices and reflecting on them. The most appropriate description of the sources of values in Thomas and Znaniecki's work can be found in Hans Joas, who argued in his own book on values that they arise in the experiences of self-creation and self-transcendence. The creativist theme that comes to the fore in the "Introduction" to Waldek's life would come back in the later phases of Znaniecki's work, especially in The Social Role of the Man of Knowledge (1940), which was published during the author's second, long visit to the United States.

Quite in line with the progressivist set of ideas that spread through Europe and the United States at the turn of the nineteenth to twentieth centuries, Thomas and Znaniecki believed the creativist type of personality to be the major factor in fast social adaptation and to be unrivalled for its adequacy. However, Thomas and Znaniecki complained both in The Polish Peasant and in their later works that social organisation and, specifically, education, in demanding mechanical compliance with rules or habitualisation, does not live up to the principle of creativity. A perfect school would allow individuals to recognise and express the fact that their life-organisation has been accomplished by the actors themselves. This theme returns in Thomas's descriptions of suppressed wishes for new experience in The Unadjusted Girl, but more extensively in Znaniecki's work on The Social Role of the Man of Knowledge. It is in the latter work that the themes of knowledge evolution and its social conditions culminate. The idea of values reappears in a new form: as the link between the social roles played by individual actors and the "social circles" of these roles. There would be no rationale for any professional activity if there were no public agreement about its advantages:

Every social role presupposes that between the individual performing the role, who may thus be called a "social person," and a smaller or larger set of people who participate in his performance and may be termed his "social circle" there is a common bond constituted by a complex of values which all of them appreciate positively. These are economic values in the case of a merchant or a banker and the circle formed by his clients; hygienic values for the physician and his patients; political values for a king and his subjects; religious values for the priest and his circle of lay belie- 
vers; aesthetic values for the artist and the circle of his admirers and critics; a combination of various values which fill the content of family life between the child and his family circle (Znaniecki 1940: 14-15).

As Znaniecki argues in the third chapter of his book, for centuries different sets of values mediated between academic institutions (rooted in the tradition of sacred schools) and the public, which is interested in practical knowledge and professional expertise. However, along with desacralisation, individualisation, and the independence of academic roles, the old principle of authority has been replaced in universities by an authentic demand for discovering new facts and formulating new theoretical problems. The roles of ideological gurus and theory defenders could not stand the new pattern of explorative thinking that emerged from the parting with unbelievable - but still strongly entrenched or even sacralised - knowledge. The role of scientific explorer meant that the bond with the social circle would be broken or compromised. Explorers want more than the satisfaction of popular needs: "All new developments in the history of knowledge have been due to those scientists who did more in their social roles than their circles wanted and expected them to do" (Znaniecki 1940: 164). Old social values get exposed to the danger of social disagreement, while new values are difficult to find and to define. They emerge from the practices of the explorers, who ask new theoretical questions and formulate new scientific methodologies: "There is no 'logic' of creative thought; there are no principles of the search for new knowledge comparable to the principles of the systematization of ready knowledge" (Znaniecki 1940: 168-169). Moreover, in so far as the old patterns of scholarly and academic teaching and studying fail to foster the creative type of scholar, they serve to reproduce the existing social order rather than to develop knowledge for its own sake. As Znaniecki writes with reference to traditional schools: "The school of general education, on the contrary, as an institution of the modern society serves directly the maintenance of social order - whether it be a traditional static order or a more or less dynamic new order" (1940: 155). In a brave and often overlooked conclusion, Znaniecki stresses that the gap between social and purely scientific values might be overcome on the level of the general meaning of exploratory practices. By constantly questioning the pre-existing hypotheses and relativising the seemingly stable body of knowledge, explorers create a dynamic order that is never ready-made but, in return, raises the system of knowledge "above the arbitrariness and vari- 
ability of subjective psychological experiences and impulses" (Znaniecki 1940: 192).

To conclude, Znaniecki's early idea of the intersubjectivity of values does not imply any necessity of value consensus. It rather means the mutual acknowledgement of the relativity of individual values as well as momentary sets of scientific beliefs. As a consequence, contrary to the traditional approaches, Znaniecki suspects a crisis of values in situations of little change: when old values are not questioned and no new values emerge. If values cease to be processual, they die out and are replaced by instincts and habits. This view conspicuously contradicts the classical visions of social stability but also proves that a radical alternative had been present long before the birth of symbolic interactionism.

Bibliography:

/// Abbott A., Egloff R. 2008. "The Polish Peasant in Oberlin and Chicago: The Intellectual Trajectory of W.I. Thomas," American Sociologist, vol. 39, pp. 217-258, https://doi.org/10.1007/s12108-008-9045-y.

/// Blumer H. 1939. An Appraisal of Thomas and Znaniecki's "The Polish Peasant in Europe and America", Social Science Research Council.

/// Boudon R. 2001. The Origin of Values: Sociology and Philosophy of Beliefs, Transaction.

/// Durkheim É. 1951 [1897]. Suicide: A Study in Psychology, Free Press.

/// Faris E. 1951. "Review of Social Behaviour and Personality: Contributions of William Isaac Thomas to Theory and Social Research," American Sociological Review, vol. 16, pp. 875-877.

/// Joas H. 1997. Die Entstehung der Werte, Suhrkamp.

/// Guth S., Schrecker C. 2002. "From The Rules of Sociological Method to The Polish Peasant. A Comparative View of Two Foundational Texts," Journal of Classical Sociology, vol. 3, pp. 281-298, https://doi.org/ 10.1177/1468795X02002003195.

/// Kaczmarczyk M. 2018. "When Philosophy Met Social Psychology: An Interpretation of The Polish Peasant in Europe and America," European Journal of Sociology, vol. 59, pp. 257-299, https://doi.org/10.1017/S0003975618000127. 
/// Kluckhohn C. 1951. "Values and Value-Orientation in the Theory of Action," [in:] Toward a General Theory of Action, eds. T. Parsons, E. Shils, Harvard University Press, pp. 388-433.

/// Mead G.H. 1932. The Philosophy of the Present, Open Court.

/// Ossowski S. 2000 [1967]. Z qagadnień psychologii spolecznej, Wydawnictwo Naukowe PWN.

/// Parsons T. 1937. The Structure of Social Action: A Study of Social Theory with Special Reference to a Group of Recent European Writers, McGraw-Hill.

/// Thomas E.A. 1992. "The Collaboration of William I. Thomas and Florian Znaniecki: A Significant Event in the History of Polish and American Cultural Connections," Polish American Studies, vol. 49, pp. 67-75.

/// Thomas W. 1899. "The Psychology of Modesty and Clothing," American Journal of Sociology, vol. 5, pp. 246-262.

/// Thomas W. 1901. "The Gaming Instinct," American Journal of Sociology, vol. 6, pp. $750-763$.

/// Thomas W. 1923. The Unadjusted Girl, Little Brown and Company.

/// Thomas W., Znaniecki F. 1958 [1918]. The Polish Peasant in Europe and America, 2 vols, Dover.

/// Thome H. 2008. "Value Change in Europe from the Perspective of Empirical Social Research," [in:] The Cultural Values of Europe, eds. H. Joas, K. Wiegandt, pp. 277-319.

/// Weber M. 1922. Wirtschaft und Gesellschaft. Grundriss der verstehenden Soziologie, J.C.B. Mohr (Siebeck).

/// Wiley N. 2007. "Znaniecki's Key Insight: The Merger of Pragmatism and Neo-Kantianism," Polish Sociological Review, vol. 158, pp. 133-143.

/// Znaniecki F. 1919. Cultural Reality, University of Chicago Press.

/// Znaniecki F. 1940. The Social Role of the Man of Knowledge, Columbia University Press.

/// Znaniecki F. 1987 [1909]. "Etyka filozoficzna i nauka o wartościach moralnych," [in:] F. Znaniecki, "Myśl i rzeczywistość" i inne pisma filozoficzne, Państwowe Wydawnictwo Naukowe, pp. 3-28. 
/// Znaniecki F. 1987 [1911]. "Myśl i rzeczywistość," [in:] F. Znaniecki, "Myśl i rzeczywistość" i inne pisma filozoficzne, Państwowe Wydawnictwo Naukowe, pp. 39-76.

/// Znaniecki F. 1987 [1912]. "Elementy rzeczywistości praktycznej,” [in:] F. Znaniecki, "Myśl i rzeczymistość" i inne pisma filozoficzne, Państwowe Wydawnictwo Naukowe, pp. 77-112.

/// Znaniecki F. 1987 [1913]. “Znaczenie rozwoju świata i człowieka,” [in:] F. Znaniecki, "Myśl i rzeczywistość" i inne pisma filozoficzne, Państwowe $\mathrm{W}_{\mathrm{y}}$ dawnictwo Naukowe, pp. 120-214.

/// Znaniecki F. 1987 [1914]. "Formy i zasady twórczości moralnej," [in:] F. Znaniecki, "Myśl i rzeczywistość" i inne pisma filozoficzne, Państwowe Wydawnictwo Naukowe, pp. 215-257.

\section{/// Abstract}

One of the central concepts of The Polish Peasant in Europe and America, especially highlighted in the "Methodological Note," is the relationship between values and attitudes, which frames the subsequent empirical analyses and conclusions. The aim of the present article is to reconstruct Florian Znaniecki's early idea of values in order to demonstrate its originality and later influence on his sociological contributions. As the author argues, Znaniecki's early insights with regard to values allow us to reconsider his collaboration with William Thomas and to interpret The Polish Peasant as a part of Znaniecki's long-term research programme.

Keywords:

Florian Znaniecki, William I. Thomas, The Polish Peasant in Europe and America, value, attitude, definition of situation

/// Michał R. Kaczmarczyk - studied law and sociology at the University of Gdańsk and received his PhD in Sociology in 2004 at the Nicolaus Copernicus University in Torun. Afterwards he was appointed assistant professor at the Institute of Philosophy and Sociology at the University of Gdańsk. In 2010, he received a Kosciuszko Foundation Scholarship and taught at the University at Buffalo in 2011-2012. In 2013, he 
received his habilitation at the Jagiellonian University in Cracow and was appointed associate professor at the University of Gdańsk. During his academic work, he was awarded several scholarships, including research stays at Max-Weber-Kolleg in Erfurt (2008, 2020), Albert Ludvig University Freiburg (2014), Swedish Collegium for Advanced Study in Uppsala (20152016), and the University of Copenhagen (2018). Kaczmarczyk's publications include Wstęp do socjologicænej teorii własności [Introduction to a sociological theory of property] (in Polish, 2006) for which he has received the Ludwik Krzywicki Award from the Polish Academy of Sciences, Niepostuszenstwo obywatelskie a pojecie prawa [Civil disobedience and the concept of law] (in Polish, 2010), and Aporia wolności. Krytyka teorii spotecznej [The aporia of freedom. A critique of social theory] (in Polish, 2019). He has translated into Polish several major theoretical works, including Niklas Luhmann's Social Systems (2007) and Talcott Parsons's The Social System (2009). For the latter he has received an award from the Polish Sociological Association.

ORCID: https://orcid.org/0000-0003-0828-7272

Email:wnsmka@ug.edu.pl 